\title{
c-Cbl/Sli-1 regulates endocytic sorting and ubiquitination of the epidermal growth factor receptor
}

\author{
Gil Levkowitz, ${ }^{1}$ Hadassa Wateman, ${ }^{1,5}$ Eli Zamir, ${ }^{2,5}$ Zvi Kam, $^{2}$ Shlomo Oved, ${ }^{1}$ Wallace Y. Langdon, ${ }^{3}$ \\ Laura Beguinot, ${ }^{4}$ Benjamin Geiger, ${ }^{2}$ and Yosef Yarden ${ }^{1,6}$
}

Departments of ${ }^{1}$ Biological Regulation and ${ }^{2} \mathrm{M}$ olecular Cell Biology, The Weizmann Institute of Science, Rehovot 76100 , Israel; ${ }^{3}$ Department of Pathology, The University of Western Australia, Queen Elizabeth II M edical Center, N edlands, Western Australia 6907, Australia; ${ }^{4} \mathrm{M}$ olecular Oncology Unit, DIBIT, and Instituto di N euroscienze e Biommagini del CNR, H.S. Raffaele, Milan 20132, Italy

\begin{abstract}
Ligand-induced down-regulation of two growth factor receptors, EGF receptor (ErbB-1) and ErbB-3, correlates with differential ability to recruit $\mathrm{c}-\mathrm{Cbl}$, whose invertebrate orthologs are negative regulators of ErbB. We report that ligend-induced degradation of internal ized ErbB-1, but not ErbB-3, is mediated by transient mobilization of a minor fraction of $\mathrm{c}-\mathrm{Cbl}$ into ErbB-1-containing endosomes. This recruitment depends on the receptor's tyrosine kinase activity and an intact carboxy-terminal region. The altemative fate is recycling of intemalized ErbBs to the cell surface. Cbl-mediated receptor sorting involves covalent attachment of ubiquitin molecules, and subsequent lysosomal and proteasomal degradation. The oncogenic viral form of Cbl inhibits down-regulation by shunting endocytosed receptors to the recycling pathway. These results reveal an endosomal sorting machinery capable of controlling the fate, and, hence, signaling potency, of growth factor receptors.
\end{abstract}

[Key Words: Endocytosis; ErbB/HER; protein degradation; signal transduction; tyrosine kinase]

Received June 15, 1998; revised version accepted October 6, 1998.

The ErbB family of growth factor receptors carrying an intrinsic tyrosine kinase activity constitutes a layered signaling network that includes a large family of EGFlike ligands that bind to four transmembrane receptors capable of forming ten homo- and heterodimeric combinations (for review, see Al roy and Y arden 1997). Whereas the EGF receptor (ErbB-1) binds several growth factors whose prototype is EGF, both ErbB-3 and ErbB-4 bind all isoforms of the $\mathrm{Neu}$ differentiation factor (NDF). The third layer of the network includes a large group of signaling molecules sharing one of several types of phosphotyrosine-binding (PTB) domains (e.g., an $\mathrm{SH} 2$ domain). Although nonidentical sets of signaling proteins are recruited, all ErbB receptors, like their invertebrate orthologs (Perrimon and Perkins 1997), funnel their signals into the mitogen-activated protein kinase (MAPK) pathway. The kinetics of MAPK activation and its relative potency, however, display remarkable differences that correl ate with the rate of ligand-induced endocytosis of receptors, termed down-regulation (Pinkas-Kra-

\footnotetext{
${ }^{5}$ These authors contributed equally to this work. ${ }^{6}$ Corresponding author.

E-MAIL liyarden@weizmann.weizmann.ac.il; FAX 972-8-9344116.
}

marski et al. 1996), and recruitment of c-Cbl by the activated receptor (Levkowitz et al. 1996).

$\mathrm{c}-\mathrm{Cbl}$ is the mammalian ortholog of the Sli-1 protein of Caenorhabditis el egans (Y oon et al. 1995). Genetic evidence indicated that $\mathrm{Sli}-1$ negatively regulates signaling downstream of the single nematode ErbB protein (Jongeward et al. 1995). c-C bl is a major cel lular substrate of tyrosine phosphorylation: It undergoes increased phosphorylation in response to ligand-induced stimulation of a variety of surface receptors, including the EGF receptor, Iymphokine receptors, immunogl obulin receptors, antigen receptors, and integrin receptors (Thi en and Langdon 1997, and references therein). Overexpression of c-Cbl attenuates signaling down-stream of the immunoglobulin E receptor (Ota and Samel son 1997) and the T-cell receptor (Boussiotis et al. 1997), yet the mechanism of $\mathrm{Cbl}$ action remains unknown. Here we report that $\mathrm{c}-\mathrm{C}$ bl can increase the rate of degradation of ErbB-1, but not ErbB-3. The underlying mechanism involves transient physical associations between $\mathrm{c}-\mathrm{Cbl}$ and ErbB-1 in endosomes, and subsequent ubiquitination of the degradation-destined receptors. An oncogenic viral $\mathrm{Cbl}$ appears to interfere with the sorting function of c$\mathrm{Cbl}$, thereby directing incoming receptors to the recycling pathway. 


\section{Results}

c-Cbl mediates selective degradation of Iigand-stimulated ErbB-1, but not ErbB-3

To investigate the possibility that EGF-driven ErbB-1 is destined to Iysosomal degradation because ErbB-1 can interact with c-Cbl (Levkowitz et al. 1996), whereas ErbB-3 is shunted to the recycling pathway (Waterman et al. 1998) because it cannot recruit c-Cbl, we transiently overexpressed c-cbl and erbB-1 in Chinese hamster ovary $(\mathrm{CHO})$ cells. In addition to $\mathrm{c}-\mathrm{Cbl}$, we used two deletion mutants that are schematically presented in Figure $1 \mathrm{~A}$. These are a peptide-tagged amino-terminal portion of $\mathrm{c}-\mathrm{C}$ bl analogous to the murine viral form, v$\mathrm{Cbl}$, and the complementary deletion mutant, $\mathrm{Cbl}-\mathrm{C}$ (Fig. 1A). Cells were briefly stimulated with EGF and tyrosine phosphorylation of the receptor analyzed by immunoblotting with anti-phosphotyrosine antibodies. The results of this experiment indicated that ErbB-1 underwent enhanced tyrosine phosphorylation in the presence of its ligand ( 10 -fold), but c-Cbl overexpression almost abolished this effect (Fig. 1B). Neither $\mathrm{v}$-Cbl nor $\mathrm{Cbl}-\mathrm{C}$ were active, implying that the combination of amino- and carboxy-terminal sequences is essential for the effect of $\mathrm{c}-\mathrm{C}$ bl on receptor phosphorylation.

Reblotting with anti-ErbB-1 antibodies revealed that c-Cbl overexpression led to degradation, rather than catalytic inactivation, of ErbB-1 (Fig. 1B, bottom): primarily the hyperphosphorylated form of ErbB-1, whose electrophoretic mobility is retarded, was diminished (by
$80 \%)$. This observation suggested that tyrosine phosphorylati on of the surface-local ized ErbB-1 molecules selectively targets ErbB-1 to degradation through c-C bl action. Labeling of cell surface-exposed ErbB-1 molecules by surface biotinylation confirmed this scenario (Fig. 1C): Overexpression of c-Cbl enhanced disappearance of the hyperphosphorylated form of ErbB-1. Concomitant with selective removal from the cell surface, signaling downstream of ErbB-1 was down-regulated by c-Cbl. This was exemplified by the ability of the ligand-stimulated ErbB-1 to recruit one of its major substrates, the Shc protein (Fig. 1C, bottom). In contrast with the EGF receptor, the NDF-receptor (ErbB-3) was not affected by C-Cbl (Fig. 1B). In conclusion, C-Cbl can down-regulate ErbB-1 signal ing, apparently by sel ective degradation of a hyperphosphorylated form of the receptor.

Additional support for this model was provided by analyses of ligand-induced redistribution of c-C bl. Consistent with the observation that EGF can induce physical association of its receptor with c-Cbl in living cells (Bowtell and Langdon 1995; Galisteo et al . 1995; M eisner et al. 1995; Tanaka et al. 1995), EGF treatment of cells co-overexpressing ErbB-1 and ErbB-3 Ied to rapid changes in the pattern of c-Cbl subcellular localization (Fig. 2A). Whereas in untreated cells c-Cbl exhibited reticular/vesicular distribution, it assumed a more punctate, vesicular-like, pattern in EGF-treated cells. In fact, some, but not all, c-C bl-bearing structures contai ned endocytosed molecules of ErbB-1. No such redistribution of cCbl, or ErbB-3, was noted on treatment with NDF (Fig.

Figure 1. $\mathrm{c}-\mathrm{Cbl}$, but not $\mathrm{v}-\mathrm{Cbl}$, increases degradation of ErbB-1 by its removal from the cell surface. (A) Shown are the domain structures of $\mathrm{c}-\mathrm{Cbl}$ and three derivative proteins. The following structural motifs are represented: A 7 residue-long histidine stretch $(7 \mathrm{His}), \mathrm{a}$ positively charged basic domain (Basic), a ring-finger domain (RF), a proline-rich domain (Pro-Rich), and a leucine-zipper (LZ). An influenza virus hemagglutinin (HA) epitope tag was added to the amino-terminal end of each protein. cD N As corresponding to the three natural forms of $\mathrm{Cbl}$ were transiently transfected into $\mathrm{CHO}$ cells. Forty-eight hours after transfection, cells were lysed and whole cell lysates subjected to immunoblotting (IB) with an anti-HA antibody. (B) ErbB-1 (left) or ErbB-3 (right) were transiently expressed in $\mathrm{CHO}$ cells by cotransfection with plasmids encoding the indicated $\mathrm{Cbl}$ proteins, or with a

A

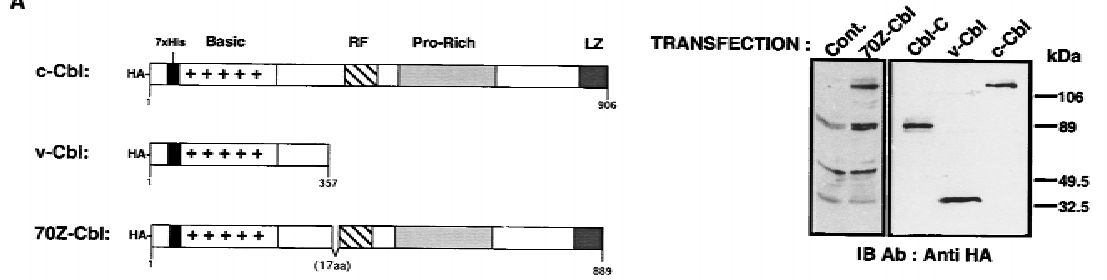

cb-c:

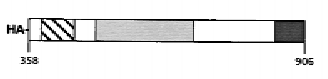

B

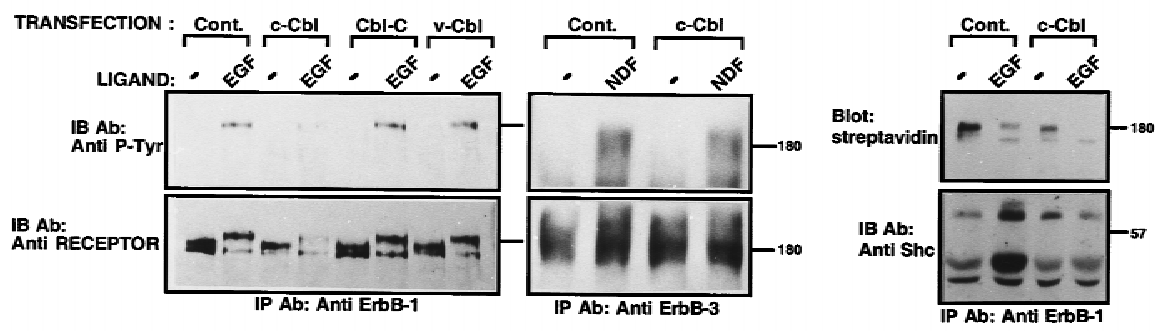

control empty plasmid (Cont.). Cells were incubated for $45 \mathrm{~min}$ at $37^{\circ} \mathrm{C}$ with EGF or NDF (each at $100 \mathrm{ng} / \mathrm{ml}$ ). Thereafter, whole cell Iysates were subjected to immunoprecipitation (IP) and immunoblotting (IB) with the indicated antibodies. (C) CHO cells were co-transfected with an ErbB-1 expression vector together with a vector directing expression of c-Cbl or a control empty vector (Cont.) Cell surface-exposed proteins were coval ently label ed with bi otin at $4^{\circ} \mathrm{C}$. Soluble bi otin was then removed and cells incubated at $37^{\circ} \mathrm{C}$ for $45 \mathrm{~min}$ in the presence or absence of EGF. Cell Iysates were subjected to immunoprecipitation (IP) with an anti ErbB-1 antibody and the electrophoretically resolved proteins were probed either with horseradish peroxidase-conjugated Streptavidin, or with an anti-Shc antibody. The locations of molecular mass markers are indicated in kilodaltons. N ote that the three Shc isoforms (p66, p52, and p46) associate with ErbB-1. 
A

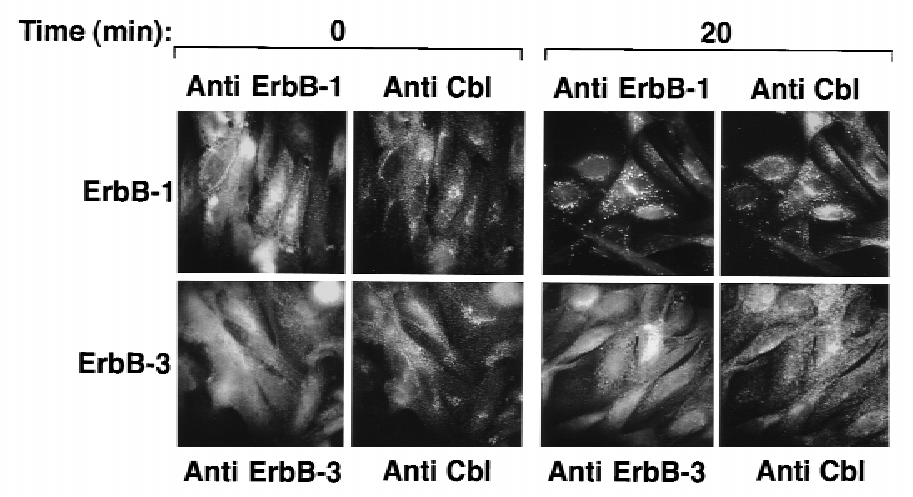

B
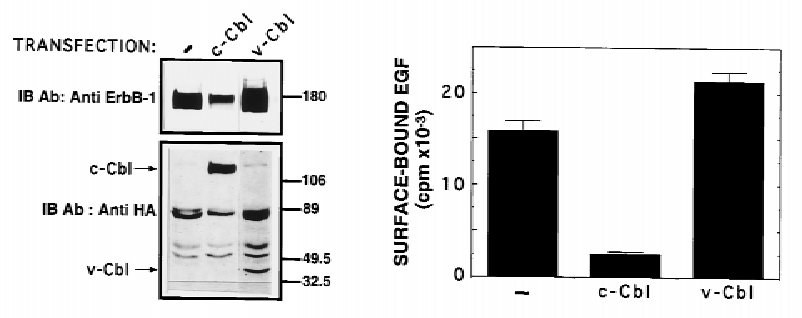

C

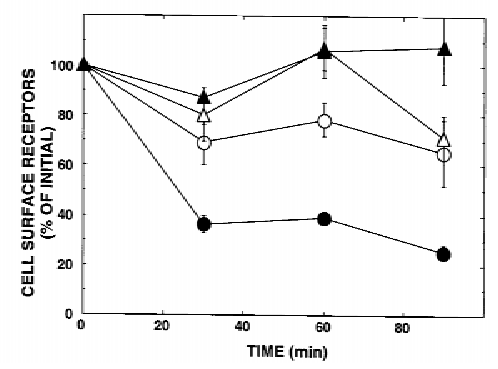

Figure 2. C-Cbl colocalizes with ErbB-1, but not with ErbB-3, and accelerates its down-regulation. (A) CHO cells that stably cooverexpress ErbB-1 and ErbB-3 (T zahar et al. 1996) were plated on cover-slips and treated at $37^{\circ} \mathrm{C}$ with EGF (top) or N DF (bottom) for the indicated periods of time. After fixation and permeabilization, cover slips were simultaneously stained with a polyclonal anti-Cbl antibody and a mAb to ErbB-1 or to ErbB-3, as indicated. Antibody detection by immunofluorescence was performed as described (M aterials and M ethods). (B) Stable CHO transfections expressing c-C bl or $\mathrm{V}$ - $\mathrm{Cbl}$ were established by cotransfection of $\mathrm{Cbl}$ constructs together with the pBABE/puro plasmid into $\mathrm{CHO}$ cells overexpressing ErbB-1 (Tzahar et al. 1996). Individual clones were screened by immunoblotting with antibodies to ErbB- 1 and to the HA tag of Cbl proteins (left, the locations of c-Cbl and v-Cbl protein bands are indicated by arrows). To assess cell surface expression of ErbB-1, clones expressing c-Cbl or v-Cbl, as well as the parental ErbB- 1 overexpressing cell line (-), were incubated for $90 \mathrm{~min}$ at $4^{\circ} \mathrm{C}$ with radiolabel ed EGF $(10 \mathrm{ng} / \mathrm{ml})$. Cell-bound radioactivity is shown as the average and range (bars) of duplicate determinations. (C) CHO cells were cotransfected with pairs of two plasmids: an ErbB-

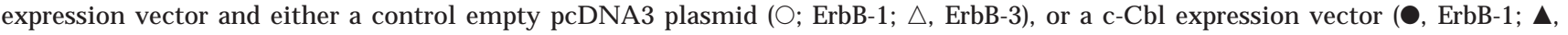
ErbB-3). Cell monolayers were subjected to a down-regulation assay $48 \mathrm{hr}$ post-transfection. The results are expressed as the average fraction (and range, bars) of original binding sites that remained on the cell surface after exposure to the nonlabeled ligand at $37^{\circ} \mathrm{C}$.

2A). This observation led us to compare the effects of c-Cbl with the abilities of the two ligands to down-regulate their binding sites. To this end, we stably expressed $\mathrm{c}-\mathrm{Cbl}$, or $\mathrm{v}-\mathrm{Cbl}$, in cells al ready overexpressing ErbB-1. Although the introduced $\mathrm{Cbl}$ proteins were detectably expressed (Fig. 2B, bottom), c-Cbl- overexpressing cells displayed a significantly lower amount of the ErbB-1 protein (Fig. 2B, left) and a six-fold decreased number of EGF-binding sites relative to control- or v-cbl-transfected cells (Fig. 2B, right). This basal down-regulation of ErbB-1 was displayed by several independently selected clones, and severely reduced the sensitivity of receptor down-regulation assays. Therefore, we used transient coexpression of a receptor and $\mathrm{C}-\mathrm{Cbl}$. Because of a high level of receptor expression, EGF treatment of ErbB-1expressing cells led to only a moderate down-regulation effect (Fig. 2C). The extent of ligand-induced down-regulation di splayed variation that apparently correlates with receptor expression, but in all experiments receptor disappearance was significantly enhanced on overexpression of $\mathrm{c}-\mathrm{Cbl}$ (Fig. 2C). This observation indicates that the amount of $\mathrm{c}-\mathrm{Cbl}$ limits down-regulation when ErbB-1 is overexpressed. In contrast, NDF treatment of ErbB-3-expressing cells did not result in receptor downregulation, and $\mathrm{c}-\mathrm{Cbl}$ exerted no significant effect on the status of NDF-binding sites (Fig. 2C). In conclusion, C$\mathrm{Cbl}$ can enhance down-regulation of the EGF-receptor, but not the NDF receptor, and this involves redistribution of c-C bl into endocytic ErbB-1-containing vesicles.

Transient ligand-induced colocalization of c-Cbl and ErbB-1 in endosomes

Because partial colocalization of ErbB-1 and c-Cbl was observed on a 20-min-long incubation of cells with EGF (Fig. 2A), we analyzed the kinetics of the phenomenon. The results presented in Figure $3 \mathrm{~A}$ demonstrate redistribution of ErbB-1 and c-C bl from their initial sites (membranal and reticular, respectively), and partial colocalization that peaks at 10-20 min. Concomitant with redistribution, the double-stained vesicular structures exhibited an apparent increase in fluorescence intensity. 
A

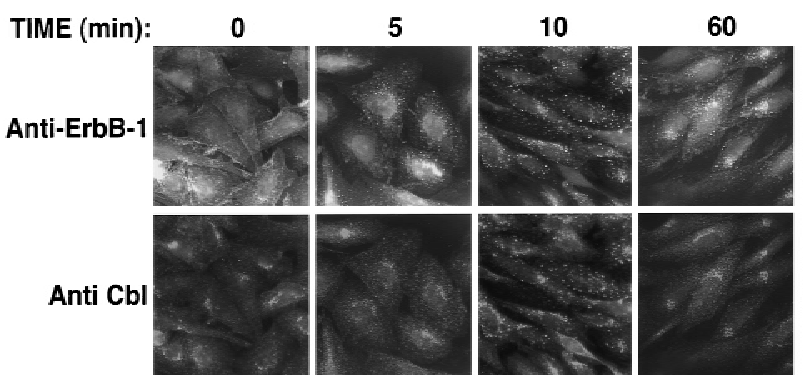

B

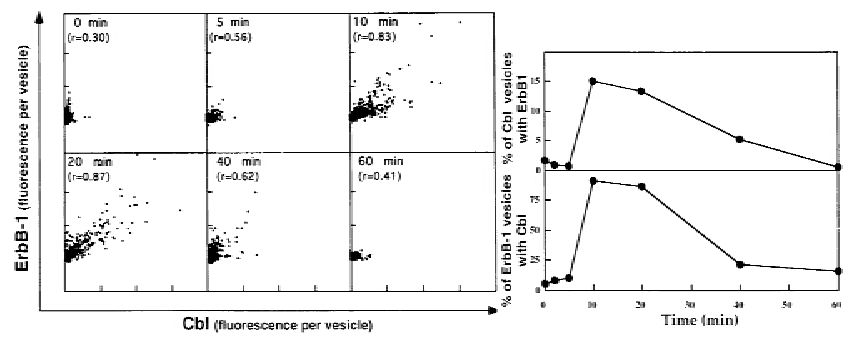

C

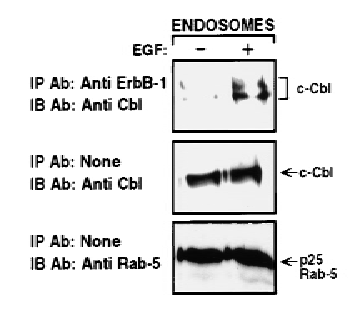

D

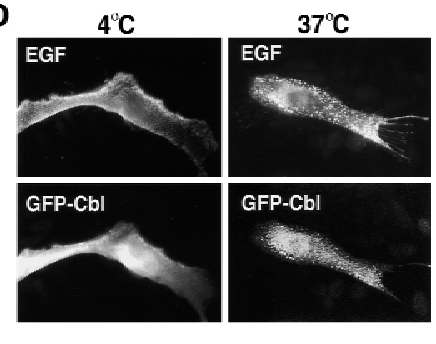

Figure 3. Time dependence of EGF-induced ErbB-1 and c-Cbl co-localization in endosomes. (A) CHO cells that coexpress ErbB-1 and ErbB-3 were either fixed $(0 \mathrm{~min})$ or first incubated with EGF for $5 \mathrm{~min}$ at $37^{\circ} \mathrm{C}$. Thereafter, EGF was removed and incubation continued for the indicated time intervals. Double staining of ErbB-1 and c-Cbl was performed and visualized as described in Materials and M ethods. (B, left) For each time point, digital images of three representative cells were segmented according to the label ing of $C \mathrm{bl}$. The fluorescence of c-C bl and ErbB-1 labeling was cal culated for each segmented vesicle. The scatter plots (arbitrary units) present ErbB-1 fluorescence vs. the c-Cbl fluorescence in each segmented vesicle. The correlation coefficient ( $r$ ) indicates the strength of a linear correlation between ErbB-1 and c-Cbl fluorescence. (B, right) $\mathrm{Cbl}$-segmented vesicles, which showed ErbB-1 positivity above a threshold, were considered Cbl-vesicles with ErbB1. (Top) Percentage of those vesicles from the total number of Cbl-segmented vesicles at each time point. (Bottom) Percentage of ErbB-1 vesicles with $\mathrm{Cbl}$ from the total number of ErbB1-segmented vesicles. (C) $\mathrm{CHO}$ cells were cotransfected with ErbB-1 and c-Cbl expression vectors and cells were incubated for 15 min at $37^{\circ} \mathrm{C}$ with EGF. Control monolayers were mock stimulated ( $\rightarrow$. Endosomes were prepared as described in M aterials and M ethods and solubilized (1\% Triton $\mathrm{X}-100$ ) for $30 \mathrm{~min}$ at $4^{\circ} \mathrm{C}$. Cell lysates were cleared and subjected to immunoprecipitation (IP) and immunoblotting (IB) with the indicated antibodies. Both the endosomal marker protein Rab-5 and c-Cbl were significantly enriched in the isolated fraction relative to other fractions that were collected (bottom; data not shown). (D) CHO cells were cotransfected with ErbB-1 and an expressi on vector encoding c- $\mathrm{Cbl}$ fused in frame to a green fluorescence protein (GFP-C bl). Forty-eight hours after transfection, cells were incubated with Texas-red-labeled EGF $(0.5 \mu \mathrm{g} / \mathrm{ml})$ for $30 \mathrm{~min}$ at $4^{\circ} \mathrm{C}$ and then either transferred to $37^{\circ} \mathrm{C}$ (right), or left at $4^{\circ} \mathrm{C}$ (left), for an additional incubation of $15 \mathrm{~min}$.

This process was further analyzed by use of computerized anal ysis of di gital images. First, we defined the borders of each c-Cbl-containing particle, and then separately determined the fluorescence intensity of c-Cbl and ErbB-1 within the framed two-dimensional structure. When this was repeatedly performed at different time intervals, we obtained the results presented in Figure 3B, in which each dot represents one vesicular structure. In untreated cells, labeling for $\mathrm{c}-\mathrm{Cbl}$ in individual particles was very low, but the cells contained relatively large numbers of small particles. Following $10 \mathrm{~min}$ of incubation, a coordinated increase in ErbB-1 and c-Cbl labeling became evident and it displayed a linear correlation coefficient of 0.83 . Colocalization was maximal after 20 min of incubation $(r=0.87)$ and then gradually declined. Analysis of the total number of intracellular vesicles/ particles per cell (data not shown), as well as the extent of colocalization (Fig. 3B, right) revealed a $25 \%$ decrease in the average density of c-Cbl-positive particles at 10 and $20 \mathrm{~min}$. The number of ErbB-1 vesicles gradually increased and reached a maxi mal level at $10 \mathrm{~min}$. Importantly, the maximal number of ErbB-1-positive vesicles was much lower than the number of c-Cbl-positive vesicles, suggesting that only a small subpopulation of c-Cbl-rich vesicles contained endocytosed ErbB-1 molecules. This was confirmed by direct evaluation of the extent of colocalization: Approximately $15 \%$ of c-C blpositive vesicles also contained ErbB-1, implying that nearly all of the ErbB-1-containing vesicles became associated with c-Cbl.

Biochemical analyses that involved labeling of surface ErbB-1 molecules with biotin, or selective immunoprecipitation of the membranal EGF receptors, indicated that only the endocytosed receptor fraction physically recruited c-Cbl (data not shown), consistent with the endosomal site of interaction implied by the immunofluorescence results. Indeed, separation of the endosomal fraction from $\mathrm{CHO}$ cells by use of the method described previously (Wada et al. 1992) and Rab-5 as an endosome marker revealed that $\mathrm{c}-\mathrm{Cbl}$ is a resident protein of the endosome (Fig. 3C). In addition, physical interaction between c-C Cl and ErbB-1 was detectabl e in the endosomal fraction only if cells were treated with EGF prior to lysis and subcellular fractionation. $\mathrm{c}-\mathrm{Cbl}$ and ErbB-1 redistri- 
bution was independently supported by use of a fluorescently label ed EGF, and c-Cbl fused to a GFP. The results presented in Figure 3D confirmed that the ligand-occupied receptor molecules colocalize with $\mathrm{Cbl-containing}$ vesicles.

c-Cbl and v-Cbl differently affect sorting of endocytosed ErbB-1 molecules

Determination of the rate of intracellular accumulation of EGF revealed that neither $\mathrm{c}-\mathrm{Cbl}$ nor $\mathrm{V}-\mathrm{C}$ bl affected the rate of ligand uptake (Fig. 4A), impl ying that $\mathrm{Cbl}$ acts at a step distal to receptor binding and coated pit-mediated internalization. This conclusion was also supported by short time (1-5 min) ligand uptake experiments, and analyses of the rate of EGF degradation, which was not affected by c-Cbl or v-Cbl (data not shown). On the other hand, examination of the receptor's fate, by use of a down-regulation assay indicated that c-Cbl, unlike $\mathrm{v}-\mathrm{Cbl}$, significantly accelerated the rate of receptor down-regulation (Fig. 4B). A surprising effect of $\mathrm{v}-\mathrm{Cbl}$, however, was revealed on the background of the extensive $\mathrm{C}-\mathrm{C}$ bl-induced down-regulation (Fig. 4B). Following a rapid phase of partial ligand-induced down-regulation, $\mathrm{v}-\mathrm{Cbl}$ caused an almost complete recovery of ErbB-1 to its original surface level. This effect of $\mathrm{v}-\mathrm{C}$ bl was sensitive to monensin (Fig. 4B, right), a carboxylic ionophore that exerts diverse intracellular effects, including disruption of recycling of EGF-occupied ErbB-1 molecules after their endocytosis (Basu et al. 1981). Conceivably, whereas c-Cbl can direct ErbB-1-loaded endosomes to degradation, $\mathrm{v}-\mathrm{Cbl}$ antagonizes this sorting function, and directs the receptors to the alternative recycling pathway.
Kinase activity and an intact carboxy-terminal region are obligatory for $\mathrm{Cbl}$-induced down-regulation of ErbB-1

If c-Cbl plays a causative role in receptor down-regulation, as implied by our results, then its interaction with ErbB-1 may depend on kinase activity and autophosphorylation sites. This question was addressed by coexpressing a series of ErbB-1 mutant proteins, together with $\mathrm{c}-\mathrm{Cbl}$, in $\mathrm{CHO}$ cells. The mutant proteins, along with a wild-type receptor, are schematically depicted in Figure 5A. They include a kinase-defective form ( $\mathrm{Kin}-1)$, a deletion mutant lacking 214 amino acids of the carboxyterminal region (denoted Dc-214), and a protein whose five major tyrosine autophosphorylation sites were replaced by phenylalanines (denoted F5). In addition, we analyzed a receptor mutated at tyrosine 974 (denoted A 974) because this site has been implicated in the interactions of ErbB-1 with the AP-2 adaptor of clathrincoated pits (Sorkin et al. 1996). Likewise, a receptor mutated at both tyrosine residues 974 and 992 (denoted Y 5,6A) was analyzed because these sites are homol ogous to the reported $\mathrm{Cbl}$-docking site of the ZAP-70 tyrosine kinase (Lupher et al. 1997). Transient expression of the mutated proteins in $\mathrm{CHO}$ cells resulted in receptor levels similar to that of the wild-type ErbB-1 (Fig. 5A). The following aspects of $\mathrm{Cbl}$ interaction with ErbB-1 were analyzed by use of this cellular system: ligand-induced physical association, as well as tyrosine phosphorylation, of c-Cbl, recruitment of Shc, and receptor downregulation. The results of these assays are summarized in a table (Fig. 5A), and presented in Figure 5, B and C. The results obtained with $Y 5,6 A$ are presented only in the table.

Evidently, two features of ErbB-1 are essential for pro-
A

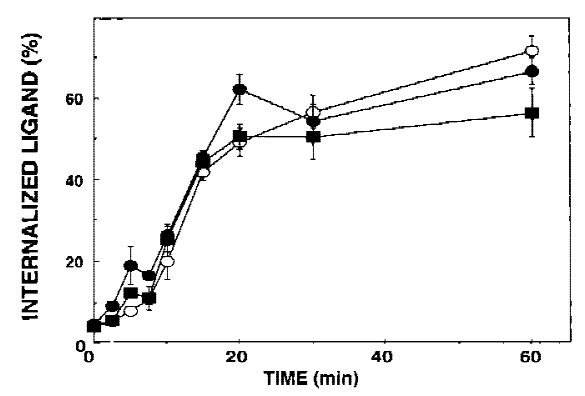

B

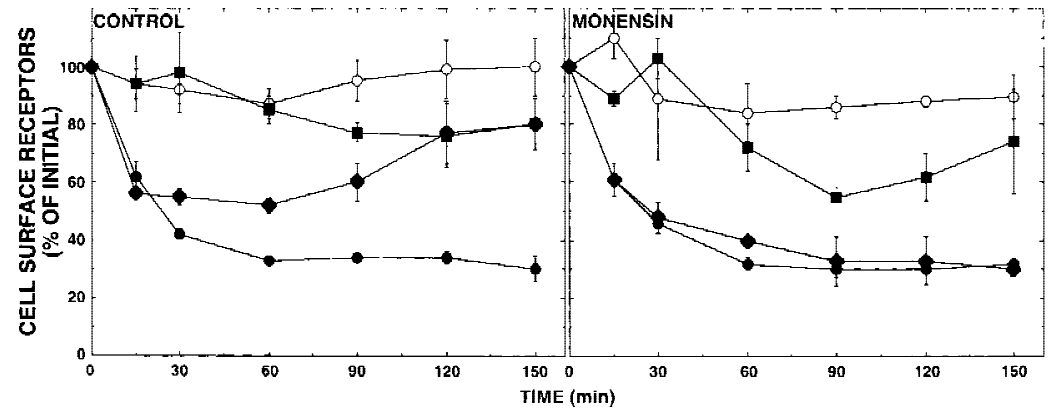

Figure 4. $\mathrm{v}-\mathrm{Cbl}$ promotes receptor recycling, whereas c-Cbl induces receptor down-regulation. (A) Ligand internalization analyses. $\mathrm{CHO}$ cells were cotransfected with an ErbB-1 vector along with one of the following plasmids: pCDNA3 (control, O), c-Cbl expression vector (๑), or a plasmid directing $\mathrm{v}-\mathrm{Cbl}$ expression (घ). Cell monolayers were treated for $2 \mathrm{hr}$ at $4^{\circ} \mathrm{C}$ with ${ }^{125} \mathrm{I}$-labeled EGF (at $10 \mathrm{ng} / \mathrm{ml}$ ) and then transferred to $37^{\circ} \mathrm{C}$ for the indicated periods of time. The fraction of internalized ligand was determined by use of a low-pH wash. Each data point represents the average \pm S.E. (bars) of triplicate measurements. (B) $\mathrm{CHO}$ cells were cotransfected with an ErbB-1-encoding plasmid along with an expression vector encoding $\mathrm{v}-\mathrm{Cbl}(\boldsymbol{\square}), \mathrm{c}-\mathrm{Cbl}(\boldsymbol{\bullet})$, both $\mathrm{v}$ - and c$\mathrm{Cbl}(\diamond)$, or with an empty vector (control, $\bigcirc$ ). Cells were rinsed and incubated at $37^{\circ} \mathrm{C}$ for the indicated periods of time with EGF (at $250 \mathrm{ng} /$ $\mathrm{ml}$ ). Sister cultures were similarly treated, except that monensin $(100 \mu \mathrm{m})$ was added to the medium. Down-regulation assays were performed as described in M aterials and M ethods. 
A
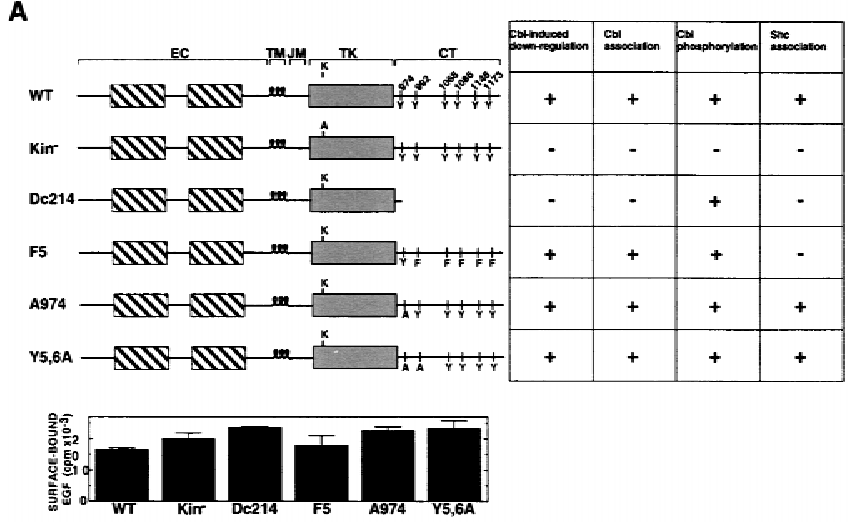

B
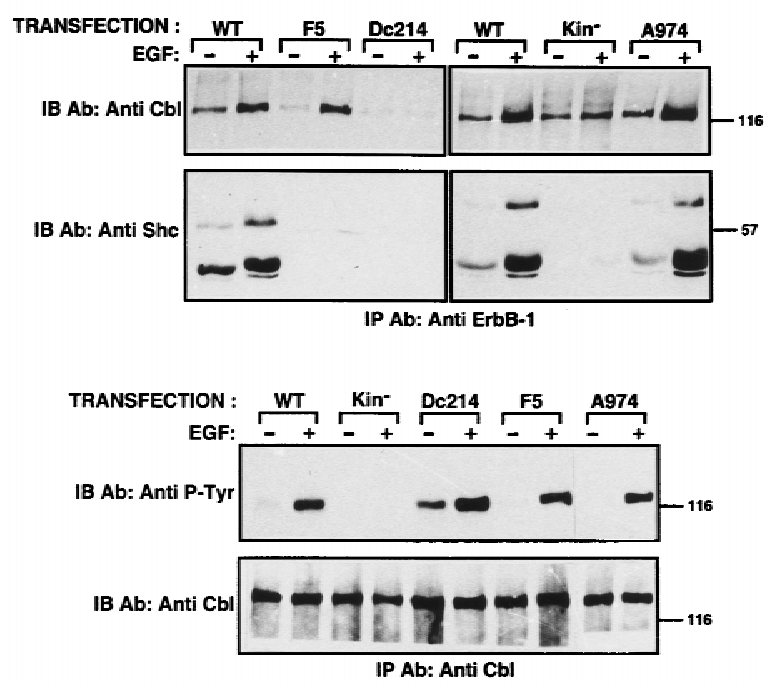

C

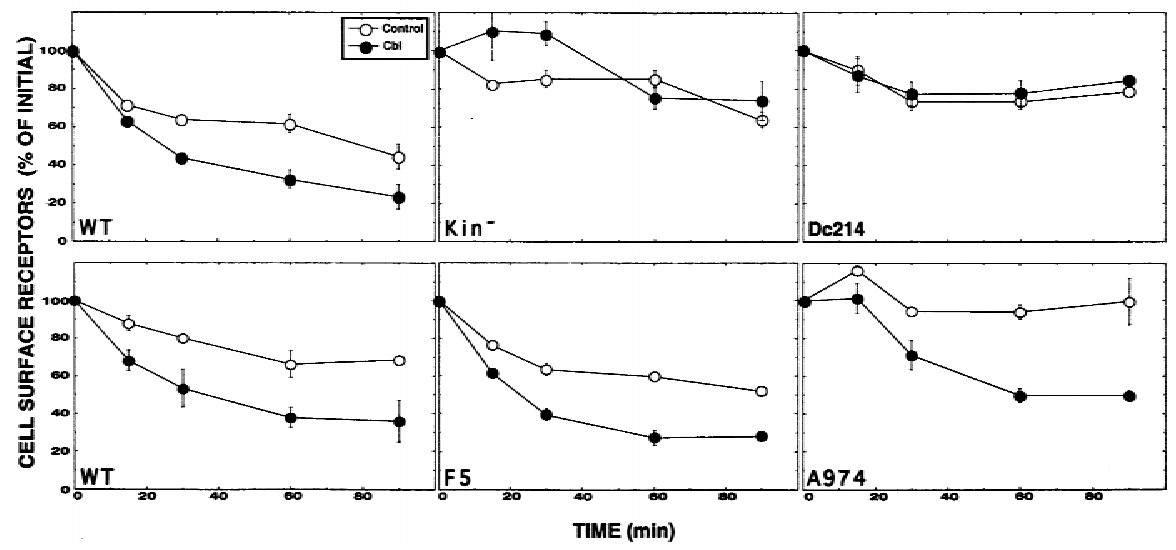

Figure 5. Structural determinants of ErbB-1 that are essential for functional interactions with c-C bl. (A) Schematic representation of ErbB-1 mutants and their interactions with c-Cbl. The domain structure of ErbB-1 is shown by boxes that correspond to the double cysteine-rich domain of the extracellular (EC) regi on, the transmembrane domain (TM), the juxtamembrane domain (JM), the tyrosine kinase (TK) domain, and the carboxy-terminal tail (CT). The five major tyrosine autophosphorylation sites, al ong with the $\alpha$-adaptin tyrosine-based internalization signal $\left[Y^{974}\right.$; (Sorkin et al. 1996)] are indicated. The ATP-binding lysine residue $\left(K^{721}\right)$ was mutated to an alanine residue in the kinase-defective mutant (Kin 7 ). A carboxy-terminal del etion mutant (Dc214) lacking 214 carboxy-terminal amino acids, and an ErbB-1 mutant in which the five major tyrosine phosphorylation sites were mutated to phenylalanine (F5) have been described previously (Sorkin et al. 1996). A double tyrosine to alanine mutant (Y5,6) is also shown. A summary of the results shown in $B$ and $C$ is presented in the table. The histogram presents the results of an assay that determined the binding of radioactive EGF to the surface of cells transiently expressing the indicated mutants. (B) M onolayers of CHO cells were separately cotransfected with plasmids encoding the indicated ErbB-1 mutants together with a c-Cbl-encoding vector. Sister plates were incubated for 15 min at $37^{\circ} \mathrm{C}$ with or without EGF (at $100 \mathrm{ng} / \mathrm{ml}$ ). Thereafter, whole cell lysates were subjected to immunoprecipitation (IP) and immunobl otting (IB) with the indicated antibodies. (C) The indicated ErbB-1 mutants were introduced into $\mathrm{CHO}$ cel Is by cotransfection with a control vector $(\bigcirc)$ or a c-Cbl plasmid $(\bullet)$. EGF-induced down-regulation assay was then performed.

ductive interaction with c-Cbl. These are the intrinsic tyrosine kinase activity, and the presence of an intact carboxy-terminal region. The five autophosphorylation sites of ErbB-1 are not crucial for the interaction between C-Cbl and ErbB-1 (Fig. 5), although they were essential for physical association with another ErbB-1 substrate, namely Shc (Fig. 5B). In accordance with their inability to interact with $\mathrm{c}-\mathrm{Cbl}$, the $\mathrm{Kin}^{-}$and the Dc214 mutants displayed markedly reduced ligand internalization and down-regulation (Sorkin et al. 1992; Chang et al. 1993).
We note that in some experiments basal association be tween $\mathrm{c}-\mathrm{C}$ bl and a kinase-defective mutant of ErbB-1 was detectable (cf. Figs. 5B and 7B), but in no case was it ligand dependent. Interestingly, the carboxy-terminally deleted mutant of ErbB-1 mediated both prolonged activation of the MAPK pathway (data not shown) and enhanced tyrosine phosphorylation of C-Cbl (Fig. 5B, bottom). Nevertheless, it was refractory to the c-Cbl-induced down-regulation effect (Fig. 5C), implying that $\mathrm{c}-\mathrm{Cbl}$ phosphorylation is insufficient for degradation of 
ErbB-1. On the other hand, complex formation between C-Cbl and ErbB-1 correlated with down-regulation (Fig. $5 A$ ), suggesting that stable physical association of c-C bl with the receptor is critical for directing ErbB-1 to degradation.

\section{c-Cbl increases ligand-induced ubiquitination of ErbB-1}

$\mathrm{N}$ ext, we addressed the effect of c-Cbl on receptor degradation by using chloroquine, an inhibitor of prelysosomal / lysosomal proteol ysis. Chloroquine exerted no effect on the limited ability of EGF to induce degradation of an overexpressed ErbB-1 in CHO cells ( $20 \%$ of ErbB-1 molecules underwent degradation following EGF treatment, regardless of chloroquine presence, Fig. 6A). Cooverexpression of c-Cbl significantly enhanced ligandinduced degradation of ErbB-1 (80\% of ErbB-1 molecules underwent degradation), but chloroquine was able to partly attenuate this Cbl-mediated enhanced degradation (only $44 \%$ of ErbB-1 molecules underwent degradation). Conceivably, c-Cbl affects receptor processing upstream to the chl oroquine-sensitive late endosomal step. Because ligand-induced ubiquitination of ErbB-1 precedes its intracel lular degradation, and it depends on endocytosis of the ligand-receptor complexes (GalchevaGargova et al. 1995), we analyzed the ability of c-Cbl to affect receptor ubiquitination. In line with previous reports, we detected a ligand-induced increase in ErbB-1 ubiquitination (Fig. 6B). By overlapping anti-ErbB-1 immunoblots with the ubiquitin signals, we learned that the ubiquitinated fraction of ErbB-1 was minor $(<5 \%$, open arrow in Fig. 6B). Overexpression of C-Cbl dramati- cally increased the amount of ubiquitin that underwent covalent attachment to ErbB-1 (Fig. 6B), implying that the cellular level of $\mathrm{Cbl}$ critically controls the extent of receptor ubiquitination.

In experiments that are not presented, we found that treatment of cells with an inhibitor of proteasomal activity, MG132, increased the extent of receptor ubiquitination in cells overexpressing c-C bl. Therefore, weanalyzed the effect of MG132 on the fraction of surfaceexposed receptors by using a down-regulation assay. The presence of MG132 decreased not only the basal EGFinduced disappearance of ligand binding sites, but also the accelerated down-regulation that was promoted by an overexpressed c-C bl (Fig. 6C). Because inhibition of either C-Cbl (Fig. 4B) or proteasomes (Fig. 6C) can enhance recycling of ErbB-1, but blocking lysosomal hydrolases allows no recycling (data not shown), it is likely that $\mathrm{c}-\mathrm{Cbl}$ acts upstream to the proteasomal and Iysosomal degradation processes.

Ligand-dependent ubiquitination corresponds to the down-regulation activity of mutant $\mathrm{Cbl}$ and ErbB-1 proteins

The contention that c- $\mathrm{C}$ bl can accel erate the degradation rate of receptor molecules by increasing their ubiquitination predicts that mutant $\mathrm{Cbl}$ proteins, which are unable to down-regulate ErbB-1, will be defective in inducing receptor ubiquitination. The two oncogenic forms of c-Cbl, v-Cbl, and 70Z-Cbl, a del etion mutant lacking 17 internal amino acids (Langdon et al. 1989), were either unable to enhance receptor down-regulation and ubi quitination or el evated receptor expression (Fig. 7A). Like-
A
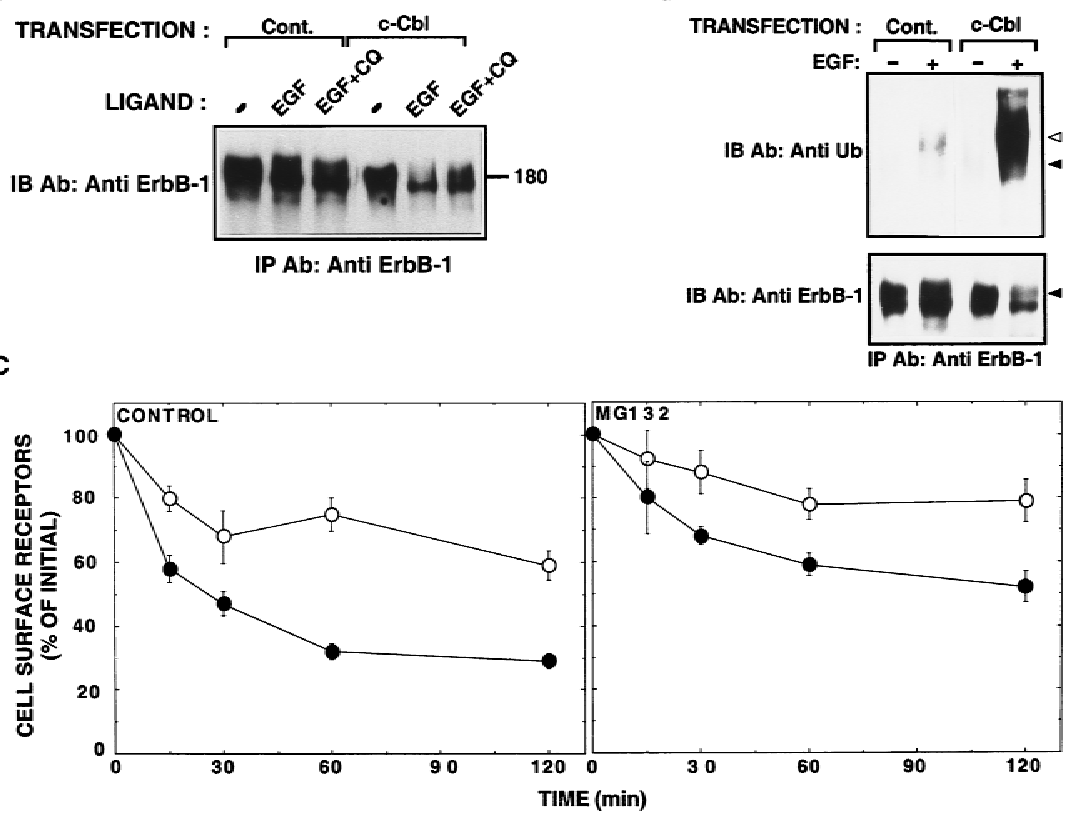

Figure 6. c-C bl-induced down-regulation involves an increase in ErbB-1 ubiquitination. (A) Chloroquine sensitivity. The wild-type form of ErbB-1 was expressed in $\mathrm{CHO}$ cells by cotransfection of an erbB-1-encoding plasmid together with either a c-Cbl-expression vector or an empty vector (Cont.). Cells were incubated for $45 \mathrm{~min}$ at $37^{\circ} \mathrm{C}$ in the absence or presence of EGF (at $100 \mathrm{ng} / \mathrm{ml}$ ) and chloroquine $(\mathrm{CQ}, 0.1 \mathrm{~mm})$. Cell lysates were prepared and subjected to immunoprecipitation (IP) and immunoblotting (IB) with anti-ErbB-1 antibodies. (B) CHO cells were transfected and treated as in A. Cell lysates were subjected to immunoprecipitation (IP) with antibodies to ErbB-1 and immunoblotting (IB) with antibodies to either ubiquitin (Ub) or ErbB-1. (Closed arrowheads) The major band of ErbB-1; (open arrowheads) the minor fraction that underwent ubiquitination. (C) ErbB-1 was transiently expressed in $\mathrm{CHO}$ cells by cotransfection with either an empty expression vector (control, $\bigcirc$ ) or a c-Cbl expression vector (๑). EGF-induced down-regulation of ErbB-1 was determined in the presence or absence of the proteasomal inhibitor MG132 (10 $\mu \mathrm{M})$. 
Figure 7. Effect of $\mathrm{Cbl}$ proteins on ubiquitination of ErbB-1 and its mutants. (A) $\mathrm{CHO}$ cells were cotransfected with a plasmid encoding ErbB-1 together with vectors directing the expression of the indicated $\mathrm{Cbl}$ proteins. An empty vector was used for control (Cont.). Cell monolayers were treated for $15 \mathrm{~min}$ at $37^{\circ} \mathrm{C}$ with EGF (100 $\mathrm{ng} / \mathrm{ml}$ ). Thereafter, we either analyzed cell lysates by immunoprecipitation (IP) and immunoblotting (IB) with the indicated anti bodies (left, arrowheads are as in Fig. 6) or performed a ligand-binding assay as described in the legend to Fig. 2B. (B) M onolayers of $\mathrm{CHO}$ cells were transfected with a plasmid expressing c-cbl or a control empty vector ( $\rightarrow$ together with vectors encoding the wild-type form (WT) of ErbB-1, or the indicated mutants. Cell monolayers were treated with EGF as in A and their whole lysates subjected to immunoprecipitation (IP) with an antibody directed to the extracellular portion of ErbB-1. Immunoblotting (IB) was performed with an antiserum to ubiquitin, or with an antibody directed to the most carboxy-terminal 14 amino acids of ErbB-1. To confirm expression of the Dc214 mutant of ErbB-1, which was not recognized by the immunoblotting antibody, we performed a ligand-binding assay on living cells (data not shown).

wise, mutant ErbB-1 proteins that cannot stably recruit c-Cbl displayed no ubiquitination. These are a kinasedefective receptor, and a carboxy-terminally deleted ErbB-1 (Fig. 7B). However, a receptor whose five major autophosphorylation sites were mutated (F5) retained enhanced ubiquitination (data not shown), in line with its ability to recruit c-Cbl (Fig. 5). Because the defective mutants were unable to associate with c-Cbl and accelerate receptor down-regulation and degradation (Figs. 5 and 7B), we concluded that functional interaction with c-Cbl is necessary for receptor degradation, down-regulation, and ubiquitination. The relative order of these processes and their presumed compartmentalized orga- nization are discussed below and summarized in a model (Fig. 8).

\section{Discussion}

Endocytosis of the ErbB-1 is one of the best-characterized routes of induced internalization of ligand-receptor complexes (for review, see Sorkin and Waters 1993; Trowbridge et al. 1993). The most rapid endocytic pathway, which utilizes clathrin-coated pits and vesicles, is characterized by saturability: The rate of internal ization decreases with increasing receptor occupancy (Lund et al.
Figure 8. Proposed model of ligand-induced endocytosis of ErbB-1. The model summarizes the major steps of receptor endocytosis and indicates their presumed time scale. Ligand binding to ErbB-1 molecules, probably by elevating autophosphorylation (encircled P), induces their interactions with clathrin-coated areas of the plasma membrane, which rapidly invaginate to form coated pits. c-Cbl may not affect excision of the pit to form a coated vesicle and the subsequent rapid uncoating process. c- $\mathrm{Cbl}$ recruitment to endosome-located ErbB-1 molecules tags them for ubiquitination ( $\mathrm{Ub}$ ) and subsequent degradation through the combined action of prelysosomal / lysosomal acid hydrolases, as well as by proteasomal proteinases. $\mathrm{v}$ - $\mathrm{Cbl}$ shunts receptors to the default pathway, which involves recycling of vesicles back to the cell surface. This step is inhibitable by monensin.

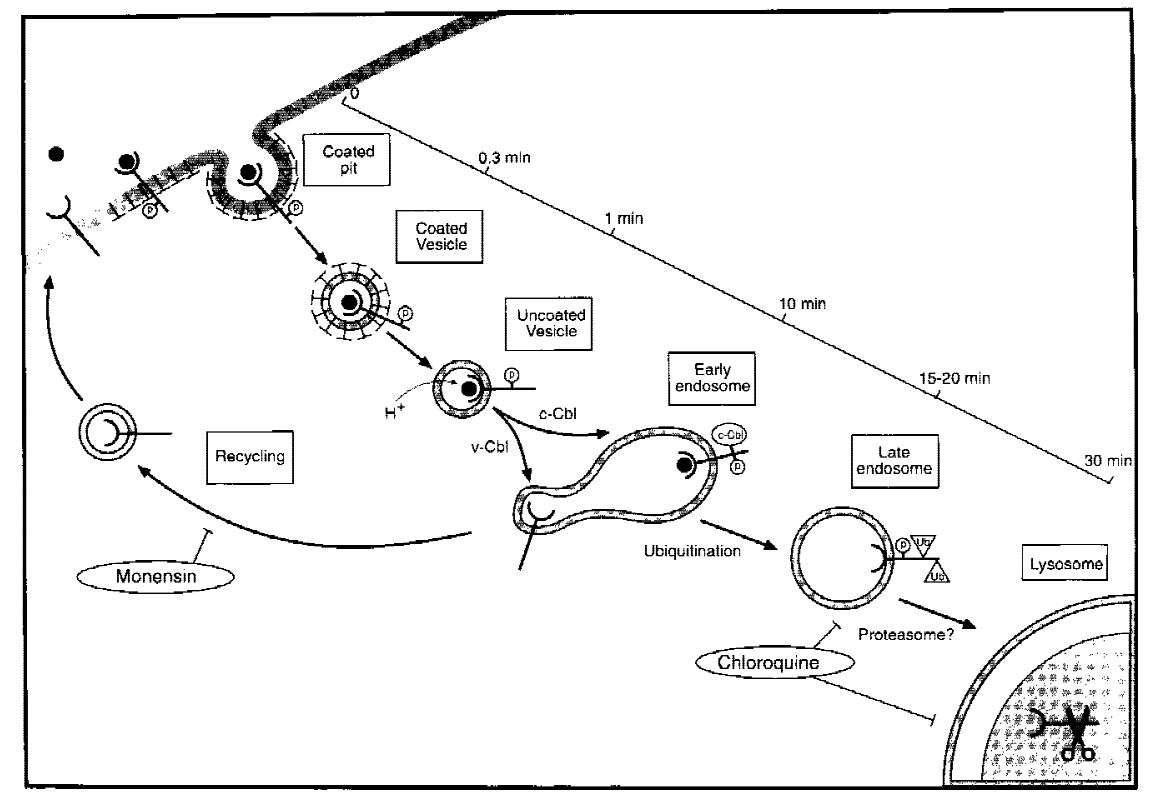


1990). A nother limiting step is the sorting of internalized receptors to lysosomal degradation (French et al. 1994). On transient overexpression of ErbB-1 in CHO cells $(\sim 2-$ $6 \times 10^{5}$ receptors/cell) the rapid endocytic pathway is practical ly saturated and very low receptor down-regulation occurs (Fig. 2C). Overexpression of $\mathrm{c}-\mathrm{Cbl}$ on this cellular background reveal ed a Cbl-dependent limiting step that can regulate receptor degradation (Figs. $2 \mathrm{C}$ and 4B). Similarly, the negative regulation by $\mathrm{c}-\mathrm{Cbl}$ of another tyrosine kinase, Syk, was detectable only on Cbl overexpression with recombinant vaccinia constructs (Ota and Samel son 1997).

Down-regulation is the net result of receptor degradation and recycling. Because the rate of EGF internalization was not detectably affected by $\mathrm{c}-\mathrm{Cbl}$ overexpression (Fig. 4A), but receptor down-regulation was accel erated by $\mathrm{C}-\mathrm{Cbl}$ (Fig. 4B), we propose that $\mathrm{Cbl}$ acts at a postcoated pit step. In agreement with this difference, a kinase-defective ErbB-1 mutant, which cannot interact with $\mathrm{Cbl}$, retained the ability to internalize EGF molecules and escaped degradation (Felder et al. 1990). The observation that a co-overexpressed $\mathrm{v}$ - $\mathrm{Cbl}$ can reverse c-Cbl's action by shunting internalized receptors to a monensi n-sensitive pathway (Fig. 4B) led us to the proposition that the recycling endosome (Trowbridge et al. 1993) is the site of Cbl's action. In support of this possibility, c-Cbl was localized to a vesicular compartment (Figs. 2A and $3 \mathrm{~A}$ ) and it was fractionated with an endosomal fraction (Fig. 3C). Because receptor ubiquitination was enhanced by c-C bl (Fig. 6), and its structural requirements appear to reflect c-Cbl recruitment (cf. Figs. 7 and $5 \mathrm{~A}$ ), it is conceivable that the sorting function of $\mathrm{c}-\mathrm{Cbl}$ invol ves receptor ubiquitination. The scheme presented in Figure 8 incorporates these conclusions into a model that integrates data from the present and previous studies. According to this model, c-C bl is not involved in the entrapment of EGF receptors by coated regions of the plasma membrane, and in the subsequent rapid invagination and scission that form coated pits and coated vesicles, respectively. However, 1-2 min after binding of EGF to the cell surface, $\mathrm{c}-\mathrm{Cbl}$ becomes associated with ErbB-1-containing vesicles (Fig. 3). On the basis of quantification of fluorescent images, we assume that all mature ErbB-1-contai ning vesicles associate with $\mathrm{c}-\mathrm{Cbl}$, but this recruitment engages only a small fraction of the cellular pool of Cbl (Fig. 3B).

How exactly $\mathrm{c}-\mathrm{C}$ bl is recruited by ErbB-1 remains unclear. One possiblity that we have not addressed is the involvement of several lysosome targeting motifs located at the carboxy-terminal region of ErbB-1 (Opresko et al. 1995). Although none of five tyrosine autophosphorylation sites located at this region appears essential for Cbl-ErbB-1 interactions, we cannot exclude the possibility that tyrosine autophosphorylation of ErbB-1 al so plays a role in c-Cbl recruitment. For example, phosphorylation of tyrosine residues we have not mutated may allow ErbB-1 to bind to c-Cbl either directly or indi rectly. Because $c-C b$ is found in living cel ls complexed to several proteins, like Crk, phosphatidylinositol 3'-kinase, and the Grb2 adaptor protein (M eisner et al . 1995), it is possible that c-Cbl/Grb2, or other complexes, associate with the carboxy-terminal region of ErbB-1 through compensatory tyrosine phosphorylation sites.

Biochemical and morphological studies that utilized a kinase-defective mutant of ErbB-1 revealed causal relationships between receptor occupancy, kinase activity, and the rate of internalization (Honegger et al. 1987; Chen et al. 1989; Hopkins et al. 1990). However, the role played by the catalytic activity of ErbB-1 in Iysosomal targeting is currently unclear. According to one possibility, targeting is independent of kinase activity (Wiley et al. 1991), but an alternative model implies that the intrinsic kinase can interrupt receptor recycling (Felder et al. 1990). According to this scenario, the early endocytic pathways of wild-type and kinase-impaired receptors are identical, but after 10-20 min the pathways diverge at the multivesicular body (MVB): Wild-type ErbB-1, destined for degradation, localizes to internal vesicles, whereas kinase-defective ErbB-1, destined for recycling, localizes to surface membranes of the MVBs. The coincidental peak of c-C bl recruitment by ErbB-1-containing endosomes (Fig. 3), together with the ability of $\mathrm{c}-\mathrm{Cbl}$ to promote down-regulation of wild type, but not a kinasedefective mutant of ErbB-1 (Fig. 5), strongly support the identification of $\mathrm{c}-\mathrm{Cbl}$ as the protein substrate whose recruitment by internalized receptors allows translocation into internal vesicles of the MVB. Conceivably, additional endosomal molecules are involved in thesorting mechanism. Examples of candi date sorting molecules include annexin I (Futter et al. 1993), SN X1, a homolog of a yeast vacuolar sorting protein that accelerates downregulation of ErbB-1 (Kurten et al. 1996), phosphatidylinositol 3'-kinase, (Joly et al. 1995), and Grb-2 (Wang and Moran 1996).

The relationships between proteasomal and Iysosomal degradation processes is unclear at present. However, it appears likely that ubiquitination occurs al ready in a prelysosomal compartment. In accordance with this scenario, we were unable to detect ubiquitinated ErbB-1 molecules on the surface of $\mathrm{CHO}$ cells by using biotin labeling (data not shown). This observation is consistent with reports that blocking endocytosis of either the growth hormone receptor (Govers et al. 1997) or the EGF receptor (Galcheva-Gargova et al. 1995), can prevent ubiquitination. The situation is clearly different in yeast cells: U biquitination of the Ste2p receptor, a G proteincoupl ed receptor for the $\alpha$ factor, is necessary for receptor endocytosis (Hicke and Riezman 1996). In fact, transfer of ErbB-1 to the lysosome may involve proteasomal activity because inhibition at this step still allows some receptor recycling (Fig. 6C). We note that degradation of several other growth factor receptors such as the insulinlike growth factor-1 receptor (Sepp Lorenzino et al. 1995), the PDGF-receptor (M ori et al. 1995), and the M et receptor for the scatter factor (Jeffers et al. 1997), al so depend on proteasomal activity. Thus, complete degradation of internalized ErbB-1 molecules probably involves simultaneous proteolysis by hydrolases and proteasomal proteinases at the late endosome and/or at the lysosome. 
Genetic analyses of mutant worms and flies indicated that $\mathrm{c}-\mathrm{C}$ bl functions as a major negative regulator of intercellular inductive processes controlling vulva Jongeward et al. 1995; Y oon et al . 1995) and eye (M eisner et al . 1997) devel opment, respectively. In both examples growth factor signaling is funneled into the Ras-MAPK pathway (for review, see Perrimon and Perkins 1997). The analogous mammalian signaling machinery, which is mediated by the ErbB network, also feeds into the Ras-MAPK pathway (for review, see Alroy and Yarden 1997). However, unlike ErbB-1, which is strongly coupl ed to $\mathrm{c}-\mathrm{C}$ bl, the two N DF receptors do not interact with c-C bl (Levkowitz et al. 1996). Consequently, ErbB-3 and ErbB-4 undergo no down-regulation foll owing stimuIation with NDF (Figs. 1B and 2C; data not shown), and no translocation of c-C bl into receptor-containing endosomal vesicles occurs in response to NDF binding to ErbB-3 (Fig 2A). These differences indicate that ErbB-1 is subject to negative regulation by $\mathrm{C}-\mathrm{C}$ bl, whereas ErbB-3 and ErbB-4 escape Cbl-mediated attenuation. Consequently, the mitogenic signal elicited by EGF is significantly less potent than that induced by NDF binding to ErbB-3 (Pinkas-Kramarski et al. 1996).

Our finding with ErbB-1 and ErbB-3 may be relevant to the many other growth factor receptors that interact with c-Cbl. Thus, it will be interesting to test the prediction that most $\mathrm{c}-\mathrm{Cbl}$-coupled receptors will undergo ligand-induced ubiquitination. In addition to ErbB-1, the receptors for CSF-1 (Wang et al . 1996), PDGF (M ori et al . 1995), and the scatter factor (Jeffers et al. 1997) are al so candidates for c-Cbl-mediated down-regulation through a ubiquitin-dependent process. Moreover, c-Cbl may control also nonreceptor tyrosine kinases, such as Syk (Ota and Samelson 1997), and Src (Tanaka et al. 1996). If verified, this function may account for the ubiquitous expression of c-Cbl, and for its general involvement in apparently unrelated signaling pathways.

\section{Materials and methods}

\section{Materials and antibodies}

A recombinant form of NDF- $\beta_{1177-246}$ was provided by Amgen (Thousand Oaks, CA ). Texas red-label ed EGF was from M olecular probes (Eugene, OR). Radioactive materials were purchased from Amersham (Buckinghamshire, UK). lodogen was from Pierce. Biotin-X-N HS, M G-123, and lactacystin were from Calbiochem. Rabbit anti-c-Cbl (C-15) antibodies, as well as antiErbB-3 antibodies, and a monoclonal antibody (mAb) to phosphotyrosine antibody were from Santa-Cruz Biotechnology. M urine mA bs to human ErbB-1 and ErbB-3 were from $\mathrm{N}$ eoM arkers (Fremont, CA). For immunoblot analysis of ErbB-1, Rab-5, and Shc, we used antibodies from Transduction Laboratories (Lexington, KY). Anti-ubiquitin antibody was kindly provided by Drs. S. Yokota (Yamanashi Medical University, Japan) and A. Amsterdam (Weizmann Institute, Rehovot, Israel). The antihemagglutinin (HA) mAb was purchased from Boehringer Mannheim.

\section{Construction and transfection of expression vectors}

To subclone c-cbl and 70Z-cbl into the pcDNA3 expression vector (Invitrogen) containing the HA sequence tag (a gift from Dr. Y. Haupt, Hebrew U niversity, Jerusal em, Israel ), we inserted the CDNAs into the BamHI and $\mathrm{Xbal}$ or $\mathrm{BamHI}$ and $\mathrm{Xhol}$ sites of pcDN A3, respectively. To generate the $\mathrm{v}-\mathrm{Cbl}$ and $\mathrm{Cbl}-\mathrm{C}$ truncation mutants, we similarly subcloned cDN A fragments corresponding to amino acids $1-357$ and 358-906, respectively. A GFP-Cbl expression vector was generated by replacement of $\mathrm{Cbl}$ 's stop codon with a Smal site and insertion into the Kpnl and Smal sites of pEGFP-N 1 (Clontech). Expression vectors (pcDNA3) containing the full-length cDNA of human ErbB-1 and ErbB-3 were described previously (Tzahar et al. 1996). The ErbB-1 del etion mutant lacking 214 carboxy-terminal amino acids [Dc-214 (Sorkin et al. 1992)], as well as the F5 mutant in which the five major tyrosine autophosphorylation sites were mutated to phenylalanine residues (Soler et al. 1993), and the A 974 in which tyrosine 974 was replaced by an alanine (Sorkin et al. 1996), have been described. All three mutants were subcloned into pcDN A3. To generate a kinase-defective ErbB-1 (lysine 721 mutated to al anine), and the double tyrosine to al anine mutant Y5,6A (tyrosine residues 974 and 992 mutated to alanines), we used ol igonucleotide-directed mutagenesis with T7DNA polymerase. Expression vectors were introduced to $\mathrm{CHO}$ cells by the Lipofectamine transfection method (GIBCO-BRL). The total amount of DNA in each transfection was normalized with pcDNA3 plasmid. Twenty-four hours following transfection, cells were split and assayed $24 \mathrm{hr}$ later.

\section{Ligand binding, internalization analyses, and endosome} purification

Recombinant human ligands were labeled with lodogen, and their binding to cell monolayers and internalization were performed as described (Waterman et al. 1998). An endosomal fraction was prepared as described (Wada et al. 1992) with the following modifications: monolayers of $\mathrm{CHO}$ cells were scraped, washed with PBS and resuspended in homogenization buffer (250 mm sucrose, $3 \mathrm{~mm}$ imidazole, $1 \mathrm{~mm}$ EDTA) containing protease and phosphatase inhibitors. Cells were homogenized (20 strokes, pestle B in a Dounce homogenizer) and centrifuged for $10 \mathrm{~min}$ at $1500 \mathrm{~g}$. The sucrose concentration in the postnuclear supernatant was adjusted to $1.15 \mathrm{M}$, overlaid with 1.00 and $0.25 \mathrm{M}$ sucrose cushions and centrifuged at $200,000 \mathrm{~g}$ for 1.5 $\mathrm{hr}$ (Beckman SW41-Ti rotor). Endosomes were collected at the 0.25-1.00 m sucrose interface. The endosomal marker protein Rab-5 was significantly enriched in this fraction relative to other fractions of the sucrose gradient.

Receptor down-regulation and surface biotinylation assays

Ligand-induced receptor down-regulation was measured as follows: cells grown in 24 -well plates were incubated at $37^{\circ} \mathrm{C}$ for up to $2.5 \mathrm{hr}$ with or without $250 \mathrm{ng} / \mathrm{ml}$ EGF or NDF in binding buffer, and then rinsed with ice-cold binding buffer. Surfacebound ligand molecules were removed by use of a low pH wash (Pinkas-Kramarski et al. 1996). The number of ligand-binding sites on the cell surface was then determined by incubating cells at $4^{\circ} \mathrm{C}$ with the corresponding radiolabel ed ligand for at least 1 hr. Biotinylation of cell surface proteins was performed as we described previously (Waterman et al. 1998).

Immunoprecipitation and immunoblotting analyses

Subconfluent $\mathrm{CHO}$ cells were grown in $10-\mathrm{cm}$ culture dishes, washed briefly with PBS, and incubated for $10 \mathrm{~min}$ at $37^{\circ} \mathrm{C}$ with the indicated recombinant growth factors (each at $100 \mathrm{ng} / \mathrm{ml}$ ). 
To stop activation, cells were washed with ice-cold PBS and kept on ice. Cell lysates were prepared at $4^{\circ} \mathrm{C}$. Immunoprecipitation, gel electrophoresis, and immunoblotting were performed as we described previously (Levkowitz et al. 1996).

\section{Immunofluorescence}

Cells grown on cover-slips were rinsed with serum-free medium and then treated in the absence or presence of ligands for $5 \mathrm{~min}$ at $37^{\circ} \mathrm{C}$. Thereafter, the medium was replaced and incubation was continued for the indicated time intervals. Cells were fixed for $15 \mathrm{~min}$ with 3\% paraformal dehyde in PBS. For immunofluorescent labeling, cells were permeabilized for $10 \mathrm{~min}$ at $22^{\circ} \mathrm{C}$ with PBS containing $1 \%$ albumin and $0.2 \%$ Triton $\mathrm{X}-100$. For double labeling, cover-slips were incubated for $1 \mathrm{hr}$ at room temperature with mAb 111.1 or mAb 90 (anti-ErbB-1 or -3, respectively) in combination with anti-Cbl antibodies. After wash with PBS, the cover-slips were incubated with Cy3-conjugated goat-anti-rabbit $\mathrm{F}\left(\mathrm{ab}^{\prime}\right)_{2}$ and FITC-conjugated goat-anti-mouse $\mathrm{F}\left(\mathrm{ab}^{\prime}\right)_{2}$-specific antibodies (Jackson ImmunoResearch Laboratories) for an additional $1 \mathrm{hr}$. Finally, the coverslips were mounted in Elvanol (Hoechst, Frankfurt).

\section{Q uantitative immunofluorescence microscopy}

The system used for quantitative fluorescence microscopy and image analysis will be described in detail elsewhere (E. Zamir, B.-Z. Katz, K. Yamada, B. Geiger, and Z. Kam, in prep.). Specimens were examined by use of a Zeiss Axioskope microscope (Oberkochen, Germany) with a 100/1.3 plan-Neofluar objective. Images were acquired by a scientific, 12-bit, chargedcouple devise (CCD) camera (M odel C220, Photometrics Co.). Particles were segmented by the Water algorithm following high-pass filter (subtracting from each pixel the average over $4 \times 4 \mu \mathrm{m}$ area around the particle). The parameters in Water were adjusted to the dimension of the particles, and were kept constant for all the analyses. To analyze the relationships be tween Cbl-labeled structures and ErbB-1-labeled vesicles, vesicles were segmented separately and fluorescence intensities measured for both C Cl- and ErbBl-segmented vesicles. The total number of $\mathrm{Cbl}$ - or ErbB1-containing vesicles was divided by the total cell area to yield the average number of vesicles per $10^{3}$ $\mu \mathrm{m}^{2}$. C bl-segmented vesicles that had FITC fluorescent intensity higher than a constant threshold were defined as $\mathrm{Cbl}$ vesicles with ErbB1, and their percentage from the total number of $\mathrm{Cbl}$-segmented vesicles was calculated. Similarly, the percentage of ErbB1-containing vesicles with $\mathrm{Cbl}$ from the total number of ErbB1-segmented vesicles was obtained.

\section{Acknowledgments}

In cherished memory of Yarden Weinberg (1994-1998) who died of rhabdomyosarcoma. We thank Drs. S. Y okota and A. A msterdam for anti-ubiquitin antibodies, Amar Sahay for constructing the pcDN A3/F5 mutant, and Sara Lavi for technical help. This work was supported by a grant from the $\mathrm{N}$ ational Institutes of Health (CA 72981).

The publication costs of this article were defrayed in part by payment of page charges. This article must therefore be hereby marked 'advertisement' in accordance with 18 USC section 1734 solely to indicate this fact.

\section{Note added in proof}

It has been reported very recently that $\mathrm{Cbl}$ enhances ubiquiti- nation and degradation of the PDGF receptor [S. Miyake et al. (1998) Proc. Natl. Acad. Sci. 95: 7927-7932].

\section{References}

Alroy, I. and Y. Yarden. 1997. The ErbB signaling network in embryogenesis and oncogenesis: Signal diversification through combinatorial ligand-receptor interactions. FEBS Lett. 410: 83-86.

Basu, S.K., J.L. Goldstein, R.G.W. Anderson, and M.S. Brown. 1981. M onensin interrupts the recycling of low density lipoprotein receptors in human fibroblasts. Cell 24: 493-502.

Boussiotis, V.A., G.J. Freeman, A. Berezovskaya, D.L. Barber, and L.M. N adler. 1997. M aintenance of human T cell anergy: Blocking of IL-2 gene transcription by activated Rap1. Science 278: 124-128.

Bowtell, D.D. and W.Y. Langdon. 1995. The protein product of the c-cbl oncogene rapidly complexes with the EGF receptor and is tyrosine phosphorylated following EGF stimulation. Oncogene 11: 1561-1567.

Chang, C.-P., C.S. Lazar, B.J. Walsh, M. Komuro, J.F. Collawn, L.A. Kuhn, J.A. Tainer, I.S. Trowbridge, M.G. Farquhar, M.G. Rosenfeld, H.S. Wiley, and G.N. Gill. 1993. Ligandinduced internalization of the epidermal growth factor re ceptor is mediated by multiple endocytic codes anal ogous to the tyrosine motif found in constitutively internalizing receptors. J. Biol. Chem. 268: 19312-19320.

Chen, W.S., C.S. Lazar, K.A. Lund, J.B. Welsh, C.-P. Chang G.M. Walton, C.J. der, H.S. Wiley, G.N. Gill, and M.G. Rosenfeld. 1989. Functional independence of the epidermal growth factor receptor from a domain required for ligandinduced internalization and cal cium regulation. Cell 59: 3343.

Felder, S., K. Miller, G. M oehren, A. Ullrich, J. Schlessinger, and C.R. Hopkins. 1990. Kinase activity controls the sorting of the epidermal growth factor receptor within the multivesicular body. Cell 61: 623-634.

French, A.R., G.P. Sudlow, H.S. Wiley, and D.A. Lauffenburger. 1994. Postendocytic trafficking of epidermal growth factorreceptor complexes is mediated through saturable and specific endosomal interactions. J. Biol. Chem. 269: 1574915755.

Futter, C.E., S. Fel der, J. Schlessinger, A. Ullrich, and C.R. Hopkins. 1993. Anexin I is phosphorylated in the multivesicular body during the processing of the epidermal growth factor receptor. J. Cell Biol. 120: 77-83.

Galcheva-Gargova, Z., S.J. Theroux, and R.J. Davis. 1995. The epidermal growth factor receptor is covalently linked to ubiquitin. Oncogene 11: 2649-2655.

Galisteo, M.L., I. Dikic, A.G. Batzer, W.Y. Langdon, and J. Schlessinger. 1995. Tyrosine phosphorylation of the c-cbl proto-oncogene protein product and association with epidermal growth factor (EGF) receptor upon EGF stimulation. J. Biol. Chem. 270: 20242-20245.

Govers, R., P. van Kerkhof, A.L. Schwartz, and G.J. Strous. 1997. Linkage of the ubiquitin-conjugating system and the endocytic pathway in ligand-induced internalization of the growth hormone receptor. EMBO J. 16: 4851-4858.

Hicke, L. and H. Riezman. 1996. Ubiquitination of a yeast plasma membrane receptor signals its ligand-stimulated endocytosis. Cell 84: 277-287.

Honegger, A.M., T.J. Dull, S. Felder, E. van Obberghen, F. Bell ot, D. Szapary, A. Schmidt, A. Ullrich, and J. Schlessinger. 1987. Point mutation at the ATP binding site of EGF receptor abolishes protein-tyrosine kinase activity and alters cellular 
routing. Cell 51: 199-209.

Hopkins, C.R., A. Gibson, M. Shipman, and K. Miller. 1990. M ovement of internalized ligand-receptor complexes al ong a continuous endosomal reticulum. Nature 346: 335-339.

Jeffers, M., G.A. Taylor, K.M. Weidner, S. Omura, and G.F. Vande Woude. 1997. Degradation of the M et tyrosine kinase receptor by the ubiquitin-proteasome pathway. Mol. Cell. Biol. 17: 799-808.

Joly, M., A. Kazlauskas, and S. Corvera. 1995. Phosphatidylinositol 3'-kinase activity is required at a postendocytic step in platelet-derived growth factor receptor trafficking. J. Biol. Chem. 270: 13225-13230.

Jongeward, G.D., T.R. Clandinin, and P.W. Sternberg. 1995. sli1 , a negative regulator of let-23-mediated signaling in C. elegans. Genetics 139: 1553-1566.

Kurten, R.C., D.L. Cadena, and G.N. Gill. 1996. Enhanced degradation of EGF receptors by a sorting nexin. Science 272: 1008-1010.

Langdon, W.Y., J.W. Hartley, S.P. Klinken, S.K. Ruscetti, and H.C. M orse III. 1989. v-cbl, an oncogene from a dual-recombinant murine retrovirus that induces early B-lineage lymphomas. Proc. Natl. Acad. Sci. 86: 1168-1172.

Levkowitz, G., L.N. Klapper, E. Tzahar, A. Freywald, M. Sela, and Y. Yarden. 1996. Coupling of the $\mathrm{c}-\mathrm{Cbl}$ protooncogene product to ErbB-1/EGF-receptor but not to other ErbB proteins. Oncogene 12: 1117-1125.

Lund, K.A., L.K. Opresko, C. Starbuck, B.J. Walsh, and H.S. Wiley. 1990. Quantitative analysis of the endocytic system involved in hormone-induced receptor internalization. J. Biol. Chem. 265: 15713-15723.

Lupher, M.L., Jr., Z. Songyang, S.E. Shoelson, L.C. Cantley, and H. Band. 1997. The $\mathrm{Cbl}$ phosphotyrosine-binding domain selects a D(N / D)XpY motif and binds to the Tyr292 negative regulatory phosphorylation site of ZAP-70. J. Biol. Chem. 272: 33140-33144.

Meisner, H., B.R. Conway, D. Hartley, and M.P. Czech. 1995. Interactions of $\mathrm{Cbl}$ with Grb2 and phosphatidylinositol 3'kinase in activated Jurkat cells. Mol. Cell. Biol. 15: 35713578.

Meisner, H., A. Daga, J. Buxton, B. Fernandez, A. Chawla, U. Banerjee, and M.P. Czech. 1997. Interactions of Drosophila $\mathrm{Cbl}$ with epidermal growth factor receptors and role of $\mathrm{Cbl}$ in R7 photoreceptor cell development. Mol. Cell. Biol. 17: 2217-2225.

M ori, S., K. Tanaka, S. Omura, and Y. Saito. 1995. Degradation process of ligand-stimulated platelet-derived growth factor beta-receptor involves ubiquitin-proteasome proteolytic pathway. J. Biol. Chem. 270: 29447-29452.

Opresko, L.K., C.P. Chang, B.H. Will, P.M. Burke, G.N . Gill, and H.S. Wiley. 1995. Endocytosis and Iysosomal targeting of epidermal growth factor receptors are mediated by distinct sequences independent of the tyrosine kinase domain. J. Biol. Chem. 270: 4325-4333.

Ota, Y. and L.E. Samelson. 1997. The product of the proto-oncogene c-cbl: A negative regulator of the Syk tyrosine kinase. Science 276: 418-420.

Perrimon, N. and L.A. Perkins. 1997. There must be 50 ways to rule the signal: The case of the Drosophila EGF receptor. Cell 89: 13-16.

Pinkas-Kramarski, R., L. Soussan, H. Waterman, G. Levkowitz, I. Alroy, L. Klapper, S. Lavi, R. Seger, B. Ratzkin, M. Sela, and Y. Yarden. 1996. Diversification of $\mathrm{N}$ eu differentiation factor and epidermal growth factor signaling by combinatorial receptor interactions. EMBO J. 15: 2452-2467.

Sepp Lorenzino, L., Z. Ma, D.E. Lebwohl, A. Vinitsky, and N. Rosen. 1995. Herbimycin A induces the $20 \mathrm{~S}$ proteasome- and ubi quitin-dependent degradation of receptor tyrosine kinases. J. Biol. Chem. 270: 16580-16587.

Soler, C., L. Beguinot, A. Sorkin, and G. Carpenter. 1993. Tyrosine phosphorylation of ras GTPase-activating protein does not require association with the epi dermal growth factor receptor. J. Biol. Chem. 268: 22010-22019.

Sorkin, A. and C.M. Waters. 1993. Endocytosis of growth factor receptors. BioEssays 15: 375-382.

Sorkin, A., K. Helin, C.M. Waters, G. Carpenter, and L. Beguinot. 1992. Multiple autophosphorylation sites of the epidermal growth factor are essential for receptor kinase activity and internalization. Contrasting significance of tyrosine 992 in the native and truncated receptors. J. Biol. Chem. 267: 8672-8678.

Sorkin, A., M. M azzotti, T. Sorkina, L. Scotto, and L. Beguinot. 1996. Epidermal growth factor receptor interaction with clathrin adaptors is mediated by the Tyr974-containing internalization motif. J. Biol. Chem. 271: 13377-13384.

Tanaka, S., L. N eff, R. Baron, and J.B. Levy. 1995. Tyrosine phosphorylation and translocation of the $\mathrm{c}-\mathrm{Cbl}$ protein after activation of tyrosine kinase signaling pathways. J. Biol. Chem. 270: 14347-14351.

Tanaka, S., M. Amling, L. N eff, A. Peyman, E. Uhlmann, J.B. Levy, and R. Baron. 1996. c-Cbl is downstream of c-Src in a signaling pathway necessary for bone resorption. Nature 383: 528-531.

Thien, C.B. and W.Y. Langdon. 1997. EGF receptor binding and transformation by $\mathrm{v}$-cbl is ablated by the introduction of a loss-of-function mutation from the Caenorhabditis elegans sli-1 gene. Oncogene 14: 2239-2249.

Trowbridge, I.S., J.F. Collawn, and C.R. Hopkins. 1993. Signaldependent protein trafficking in the endocytic pathway. Annu. Rev. Cell Biol. 9: 129-161.

Tzahar, E., H. Waterman, X. Chen, G. Levkowitz, D. Karunagaran, S. Lavi, B.J. Ratzkin, and Y. Yarden. 1996. A hierarchical network of inter-receptor interactions determines signal transduction by NDF/neuregulin and EGF. Mol. Cell Biol. 16: 5276-5287.

Wada, I., W.H. Lai, B.I. Posner, and J.M. Bergeron. 1992. Association of the tyrosine phosphorylated epidermal growth factor receptor with a 55-kD tyrosine phosphorylated protein at the cell surface and in endosomes. J. Cell Biol. 116: 321-330.

Wang, Y., Y.G. Yeung, W.Y. Langdon, and E.R. Stanley. 1996. c-Cbl is transiently tyrosine-phosphorylated, ubiquitinated, and membrane-targeted following CSF-1 stimulation of macrophages. J. Biol. Chem. 271: 17-20.

Wang, Z. and M.F. Moran. 1996. Requirement for the adapter protein GRB2 in EGF receptor endocytosis. Science 272: 1935-1938.

Waterman, H., I. Sabanai, B. Geiger, and Y. Yarden. 1998. AIternative intracellular routing of ErbB receptors may determine signaling potency. J. Biol. Chem. 273: 13819-13827.

Wiley, H.S., J.J. Herbst, B.J. Walsh, D.A. Lauffenburger, M.G. Rosenfeld, and G.N. Gill. 1991. The role of tyrosine kinase activity in endocytosis, compartmentation, and down-regulation of the epidermal growth factor receptor. J. Biol. Chem. 266: 11083-11094.

Yoon, C.H., J. Lee, G.D. Jongeward, and P.W. Sternberg. 1995. Similarity of sli-1, a regulator of vulval development in C. elegans, to the mammalian proto-oncogene c-Cbl. Science 269: 1102-1105. 


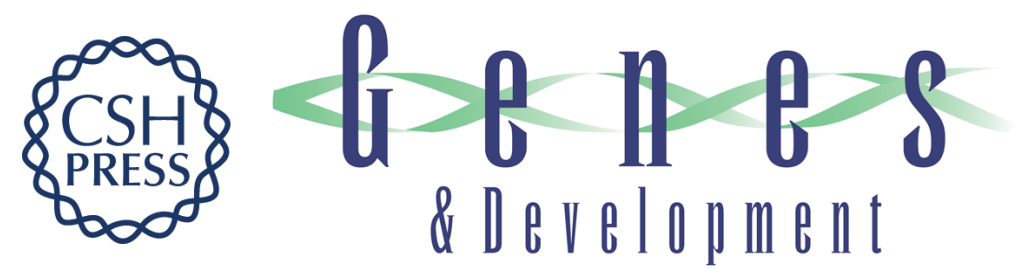

\section{c-Cbl/Sli-1 regulates endocytic sorting and ubiquitination of the epidermal growth factor receptor}

Gil Levkowitz, Hadassa Waterman, Eli Zamir, et al.

Genes Dev. 1998, 12:

Access the most recent version at doi:10.1101/gad.12.23.3663

References

This article cites 46 articles, 30 of which can be accessed free at: http://genesdev.cshlp.org/content/12/23/3663.full.html\#ref-list-1

License

Email Alerting

Receive free email alerts when new articles cite this article - sign up in the box at the top Service right corner of the article or click here.

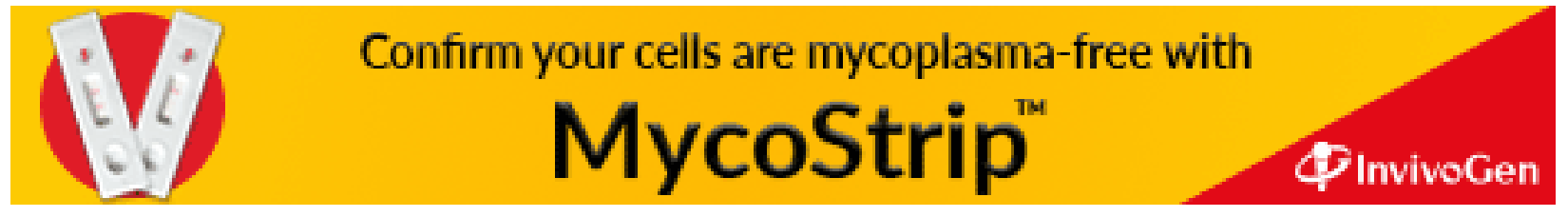

